\title{
Variation of the Word Denoting the Adverbial Modifier of Purpose as to the Position in the Simple Sentences (On the Materials of the English and Azerbaijani Languages)
}

\author{
Aytan Arif Rajabova ${ }^{1}$ \\ ${ }^{1}$ Department of Lexicology, Azerbaijan University of Languages, Baku, Azerbaijan \\ Correspondence: Aytan Arif Rajabova, Department of Lexicology, Azerbaijan University of Languages, Baku, \\ Azerbaijan. E-mail: aytan.rajabova@gmail.com
}

Received: January 19, 2014 Accepted: April 4, 2014 Online Published: May 27, 2014

doi:10.5539/ijel.v4n3p106 URL: http://dx.doi.org/10.5539/ijel.v4n3p106

\begin{abstract}
The article has been written on the basis of comparative-typological method in the study of the languages (the English and Azerbaijani languages) belonging to different language systems. The main aim of the investigation is to discover similarities and distinctions in the phonetic system of the words denoting adverbial modifier of purpose in both (English and Azerbaijani) languages and to investigate the impact of the place of the word denoting adverbial modifier of purpose on the articulatory principles in both compared English and Azerbaijani languages. The problem of variation though being a new field of linguistics, for an Azerbaijani investigator, certain work has been carried out devoted to the solution of the problem. In this research work, the character of variation and the causes forming this variation are studied.
\end{abstract}

Keywords: variation, position, the adverbial modifier of purpose, cognition

\section{Introduction}

Depending upon this, we may point out two types of variations associated with pronunciation in the speech act: variations taking place in the level of form and meaning. Depending upon the expressed thought and cognitive preparation of the speaker simple sentences are realized in different forms, because the thoughts though being the same, their forms of realization in the speech act are in different variations depending upon the theme, situation, on the level of mastering the language, on the attitude of the speaker to the happening phenomenon, on reality and non-reality of the expressed thought, on the level of information of the speaker with the expressed action, on its social state, etc.

\section{Scope of the Study}

Analysis shows that in both compared languages, sentences composing of the same structure and depending on the above-mentioned factors, when being articulated, indications of acoustic parameters change (Yunusov, 2008) As a result, different variation features take place associated with normative invariant phonetic structure of the sentences, having the same syntactic structure.

The character of variation changes depending upon the mode of speech of each speaker. In order to specify these changes experiment has been used. The facts, attained by the pronunciation of three English-speaking informants have been generalized in the table below. As an example here, we introduce the table reflecting the melodic parameters attained by the pronunciations of the informants of the sentence "So they must kill her". 


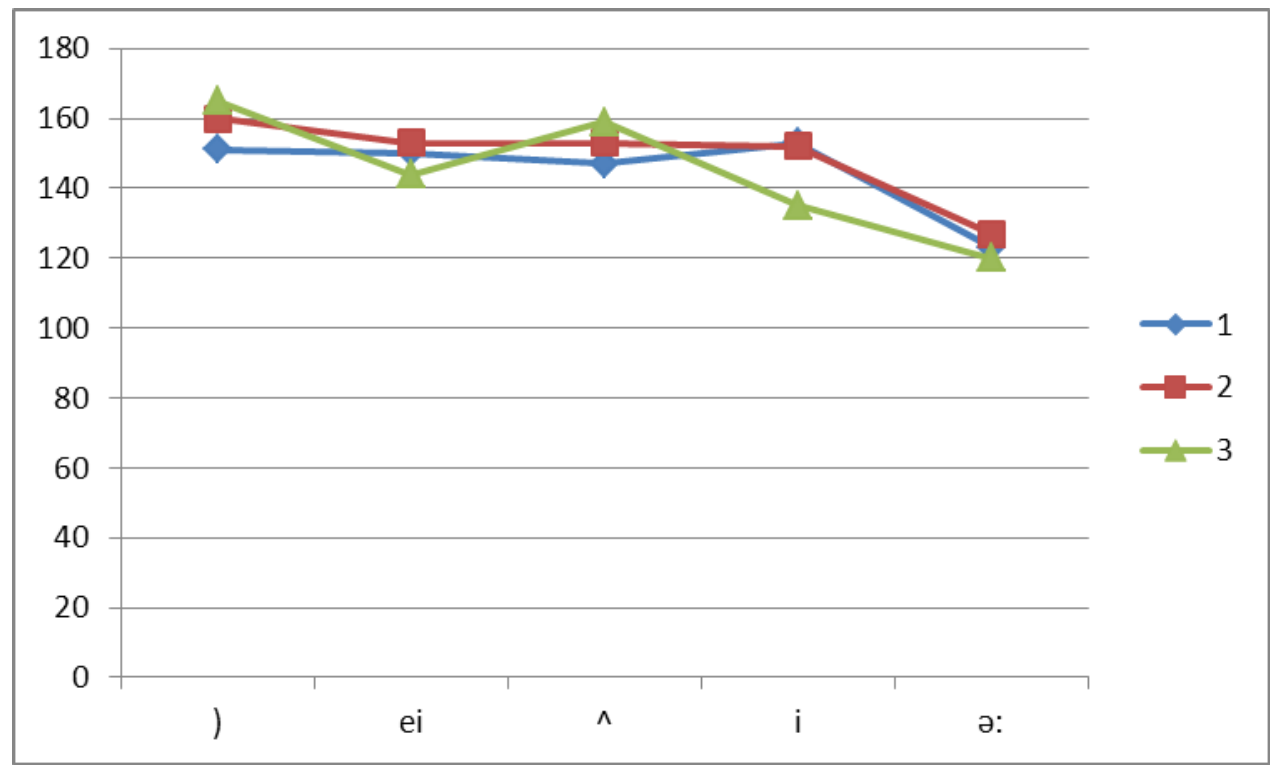

Figure 1. Table reflecting the melodic parameters

On the basis of analysis the variation features of the acoustic parameters (melodic, dynamic and temporal) have been discovered. Each simple sentence, depending on the purpose, consists of certain lexical units. These units are never arranged chaotically, their distribution is grounded on the syntactic and phonetic rules regulated by norm, as to the grammatical function of each word, forming the sentence. As it has been mentioned in the linguistic literature, the number of the members of sentence carrying out these functions is five. But there are other approaches associated with the number of the members of the sentences too (Taghizadeh, 1960).

The analysis of the materials of the compared languages shows that each member of the sentence, comprising the structure of the simple sentence, possesses its own place of usage and function. This is a phenomenon, formulated and stabilized in the history of development of the language. Each sentence though is realized by the speech act, possesses a model which is used within the norms in the system of language. Analysis shows that these models themselves are realized differently in the speech act, associated with the situation. In the English and Azerbaijani languages the members of sentences depending upon the carried out functions in the formulation of the sentences are divided into two groups: the principle and secondary members of the sentence (Abdullayev, 1998). Depending upon only the principle or alongside the principle, the secondary parts of the sentences, their information and semantic-syntactic structural features in their comparison, both within the same language and in different languages, differ from one another, in the establishment of the sentences. Within the frame of sentence the place of the members of the sentences, being not the same in different languages, is different. This differentiation shows itself in the analysis of the materials of the English and Azerbaijani languages as well. In the Azerbaijani language which represents Turkic group of languages, in the normal case, in the simple sentence predicate comes at the end of the sentence.

\section{O, oxumağa Baklya galir (He comes to Baku to study).}

Even when the sentence is expended the predicate shifts to the end of it (Modern Azerbaijani Language, 1959).

In the English language belonging to the Germanic language group the predicate in the normal declarative sentence comes in the second place.

He has come to Baku to study.

From the examples it becomes clear that in the Azerbaijani language the word "golir" bearing the function of predicate is used in the final position, whereas in the English language in the structure of the sentence the same member of the sentence "has come" is used in the second place.

In the both languages the secondary members of sentences as to the semantic and syntactic correlations are concentrated in two groups. The adverbial modifier of purpose which we analyze as the other types of adverbial modifiers in the both languages are included into the predicate group and serves in its formulation.

The old man goes to the garden to work // Qoca kişi işlaməyə bağa gedir //. 
In the both languages at the beginning of the sentence the words "old", "qoca" stand in front of the subject and semantically being linked with it all together establishes subject group. However, the other secondary parts of sentences used in the same sentence serve to establish predicate group ("goes to the market to work", "işlaməyə băga gedir").

It becomes clear from above mentioned sentences that the word carrying out the function of adverbial modifier of purpose in the English language, in the normal case, while standing after the predicate in the end of the sentence, as to the syntactic structure of the Azerbaijani language, in the normal case, it comes before the predicate, namely it stands between the subject and predicate. But depending on the aim and context in both languages the adverbial modifier of purpose in the structure of simple sentences, can be placed in different positions.

At the beginning of the sentence: - So they must kill her; in the middle: - He accidentally broke the vase. At the end: - John took a magazine to read. In the given sentences we witness the usage of adverbial modifier of purpose in three places in the sentences, depending on context. Similar position shows itself in the analysis of the Azerbaijani language as well.

At the beginning of the sentence: —Göza görünməməkdən ötrü onlar toranda yola çıxdılar. (So as to be visible they started at twilight); in the middle: — Bunu sənə uşaqlardan muğayat olasan deyə danışıram (I tell you this so that you should take care of the children). At the end of the sentence: - Galmişəm saninla maslahatlaşməyə (I have come to consult with you).

Therefore, as we see in the both languages the adverbial modifiers of purpose being included into the predicate group have possessed the possibilities to be used in different sentences in the simple sentences. But this must also be mentioned that different from the English language, in the Azerbaijani language the place of adverbial modifier of purpose is freer.

In the structure of the sentence depending on the variation of the position of the adverbial modifier of purpose, its informatics load changes too. On the view point of actual division in the first and the second sentences, adverbial modifier of purpose while belonging to the point of theme, in the third sentence the words denoting adverbial modifier of purpose are included into the group of rheme. In such a position, adverbial modifiers act as the bearers of new information.

In English sentences the members of sentences acting as adverbial modifier of purpose can't change their places as they happen in the Azerbaijani language (O, oxumağa Bakıya galir // O, Bakıya oxumağa galir // Oxumağa o, Baklya galir, etc.) the Azerbaijanians learning English as a foreign language, during the pronunciation, as a result of change of word order, sometimes face distinctive pronunciation variations, because the variative structures being possible in the word order of the Azerbaijani language is impossible for the English language. In both languages, towards the final of simple sentences with adverbial modifier of purpose, fall of main tone takes place, in the indications of melodic and dynamic parameters of intonation, which influence on the articulation of the member of the sentence coming in the final position

\section{O, oxumă̆a Baklya galib (He has come to Baku to study).}

Investigations show that in the form of this variation in the intonation structure of the sentence in the Azerbaijani language the predicate which is used at the final position (golir), is associated with influence of the adverbial modifier of purpose (to study) in the same position in the English language. In the given sentences depending upon the syntactic structure of the languages the places of predicate and adverbial modifier of purpose are different from each other. In the English language the acoustic indications (melodic, dynamic) as to the structure of the sentence, while depend on the average acoustic indications, but in the Azerbaijani language the indications reflecting the acoustic parameters of the same unit carrying out the function of adverbial modifier of purpose are not below average. In the Azerbaijani language in the second structural variation "O golir oxumağa" the word carrying out the function of adverbial modifier of purpose is used with predicate and substitutes its place with the predicate (galir). Substitution of the position of the word, denoting adverbial modifier of purpose in the word order of the sentence causes the creation of new variation, associated with the pronunciation of the word. The new variant in itself is created thanks to the alteration of the main tone and intensity in the process of pronunciation of the speaker (Yadigar, 2003) The indications of acoustic parameters of the adverbial modifier of purpose used in this function is different from the first variation, because, the infinitive "to study" denoting adverbial modifier of purpose in this structure has been used in the final position in the sentence. Depending on the position of the word "oxumağa" (to study) carrying out the function of adverbial modifier of purpose in the simple sentence, it is possible to show the variation in the pronunciation, set up in the table on the ground of analysis. 


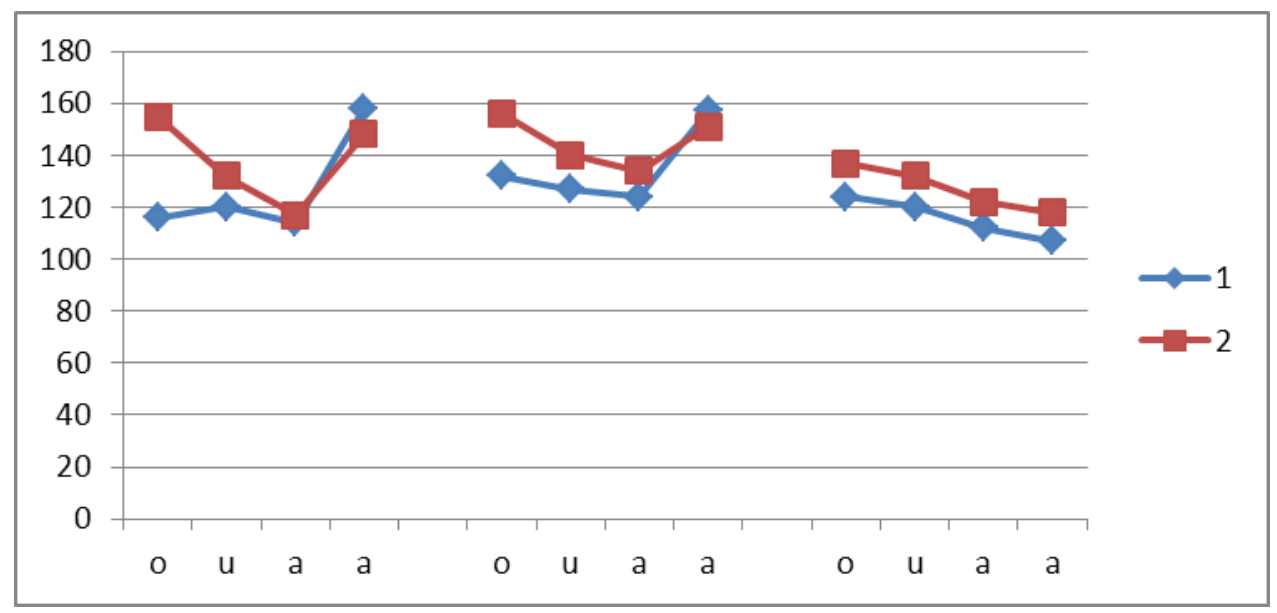

Figure 2. Variation in simple sentences

In the first sentence of the graph "/Oxumağa Bakıya galib/" the adverbial modifier of purpose "oxumağa", in the second sentence "/O, oxumağa Bakıya galib/" the adverbial modifier of purpose "oxumağa" and in the third sentence "Baklya galib oxumağa //" the adverbial modifier of purpose "oxumağa" reflect the variations taking place in the melodic structures.

It becomes clear from the analysis that the word denoting the adverbial modifier of purpose in the final position has still weaker melodic indication.

\section{Research Methodology}

We have used in this article historical and comparative typological methods in the investigation of the position of the word denoting adverbial modifier of purpose in the simple sentences.

\section{Distinction of Variation in the Temporal Indications}

Distinction in the temporal indications is also observed. The word, denoting the adverbial modifier of purpose "oxumăga" while being used in the middle position and 0,53 s. of time for pronunciation is spent, but in the pronunciation of the word denoting the same function in the final position, the time spent on its pronunciation has been $0,61 \mathrm{~s}$. which shows that the position variation of the word carrying out the function of adverbial modifier of purpose influences its temporal parameters, too. Exactly speaking, still more time is spent on the pronunciation of the word denoting adverbial modifier of purpose in the final position.

\subsection{Indication in English}

In the English language depending upon the word order, in order to determine the variation features in the pronunciation of the words denoting the adverbial modifier of purpose, the same word denoting the adverbial modifier of purpose has been used in different positions in the sentence. Ex.: 1. John was hence neglected by the teachers // 2. Hence we infer him to go to the village // etc. In these sentences the words denoting adverbial modifier of "hence" in the first sentence has been used in the middle position, but in the second sentence it has been in the front position. It has become clear from the analysis that the acoustic indications of the word "hence" denoting adverbial modifier of purpose is higher than the acoustic indications (melodic, dynamic) of the word "hence" denoting adverbial modifier of purpose.

\subsection{Indication in Azerbaijani}

In the Azerbaijani language without making any structural changes, by the prosodic means it is possible to establish forms denoting interrogative meaning. $O$, Bakıya oxumağa galir? $O$, galir oxumă̆a etc. These phonetic structures in the Azerbaijani language being accepted as norms of substitution of one (O, Baklya oxumağa galir) with the other (O, Baklya oxumağa galir?) is impossible, because in the first sentence information is given, but in the second sentence, interrogation is expressed. Each of them in the phonetic structures of the language is the invariant structures determined by normative rules of the language. In the distinction, intonation acts as a relevant feature. In the speech acts the simple sentences with adverbial modifier of purpose of such structures are realized in the speech of any bearer of the language. Besides the invariant features, they accept new variant features associated with distinctions. In the concrete speech act these additional acoustic indications, accepted by the invariant structure, ensure the distinction of numerous variations. Just thanks to the features of this variation 
even if the hearer does not see the speaker (if that person is familiar with the act of speech of the speaker beforehand) as to the shades of his voice, the listener can determine the personality of the speaker. This derives from the fact that each speaker at the same time with sending a certain information, gives information about himself (herself) too.

Associated with the variation of simple sentences with adverbial modifier of purpose similar position is also observed in the analysis of Azerbaijani sentences included into the materials of the investigation such as // Allahyar Cahandarı rüsvay etməkdən ötrü quzı qaçırdı (Allahyar had the girl run away with him so as to disgrace Jahandar), // Onu görmək namina bütün günü gözladi // (He waited all day long in order to see her), // Səni də özümla aparmaqdan ötrü galmişəm // (I have come to take you with me too). It has become clear from the analysis of the sentence that not in all simple sentences variation phenomenon in the pronunciation of adverbial modifiers of purpose is realized by the harmony of all components. (See: appendix gr. 230).

From the graphs we may easily determine that in a sentence melodic peak is not always associated with dynamic height. Sometimes informants, in order to express their attitude to the occurrence, give way to variation depending on what member of the sentence acoustic parameters are linked with in the sentence, because in a condition, when contents are absent in the sentence we witness a distinctive approach in determining the main meaning which demonstrates itself in this or that member of the sentence. In the process of reading the materials by both informants diversion from the norms - giving way to variations in the experiment materials have found their solutions as undeniable facts.

A norm in the process of pronunciation is regulated by the rules of a language and is realized in the form of variants. During the pronunciation of adverbial modifier of purpose the created variants are not something new; these variants are realized by the individual addition of the speaker to the general invariants in the process of pronunciation. In the pronunciation of simple sentences with the adverbial modifier of purpose this fact has also justified itself.

Here we may come to the conclusion that in the pronunciation of invariants of simple sentences with adverbial modifier of purpose the intended in the norm structure + individual distinction aggregate. Analysis of the materials of both languages show that if in a simple sentence the adverbial modifier of purpose is expressed not by a construction, but only by an infinitive, in the pronunciation of the speaker the variation features change, namely, in order to denote the adverbial modifier of purpose only one lexeme is used. In such a position for an informant to express the thought and to set up necessary phonetic structure doesn't create any difficulty, because in a simple sentence while carrying out its function, the adverbial modifier of purpose expressed by an infinitive becomes the only bearer of the new information and during the pronunciation it is easier to regulate its acoustic parameters.

Onlar işlaməyə gedirlar // (They go to work), // Cahandar intiqam almağa galmişdi // (Jahandar came to take his revenge), // Berlina oxumağa galmişəm // (I have come to Berlin to study), // Xəstaya baş çəkməya galmişik // (We have come to attend the patient), // Hər halda o, görməkdən, hiss etməkdən ötrü yaşasin //, (In any case, he should live to see and to feel), etc.

In these sentences the infinitives such as "işləməyə" (to work), "intiqam almağa" (to take his revenge) "oxumağa" (to study), "baş çəkməyə" (to attend), "görməkdən, hiss etməkdən ötrü" (to see, to feel) have been used as adverbial modifiers of purpose and from the point of informativity they establish the nuclear of the sentence (Yunusov, 2008). As an example here in the sentence // Onlar işlamaya gedirlar // (They go to work), we have analyzed the variation features which informants have demonstrated during the pronunciation of the sentence in which exists adverbial modifier of purpose expressed by infinitive. It became obvious to us that the adverbial modifier of purpose by the thought expressed in this sentence brought clarity to the purpose why (for what purpose) they went. In the Azerbaijani language, in conformity with the demand of the word order in the simple sentence the adverbial modifier of purpose has been expressed between the subject and the predicate and has possessed a crucial role in sending the information. Both informants have pronounced the second part of the word denoting the subject melodically in higher tone, whereas they pronounced the adverbial modifier of purpose which is used after that, with lower tone in comparison with the subject. The first part of the sentence by both dictors has been pronounced with $132 \mathrm{hz}$. tone frequency, but the intensivness indications of this syllable as to the speakers have been different, namely, for the first speaker it has been $74 \mathrm{db}$, but for the second one $61 \mathrm{db}$. In the pronunciation of the word representing the adverbial modifier of purpose variation has taken place in the junction of word "gedirlar" (they go) which is used after that too. It became clear to us that the acoustic indications in the articulation of the word indicating the predicate which is used after the adverbial modifier of purpose have been distinctive. The frequency mark of the tone of the last syllable of the infinitive denoting 
adverbial modifier of purpose for one speaker has been $142 \mathrm{hz}$, whereas for the pronunciation of the word denoting the predicate began with $113 \mathrm{hz}$, but for the second speaker this distinction has taken place between 133 hz and $117 \mathrm{hz}$.

\section{Result}

The analysis of the experimental materials attained from the pronunciation of language bearers shows that though there can be similarities between the graphs from the general phonetic structure, each of them is different from the other as to the indication of self-belonging acoustic features. This variation features in the speech act can be considered as the bearer of the information. So, we can say, that the position of adverbial modifier of purpose within the simple sentences changes the character of variation in the speech act.

The article can be crowned with the following conclusions attained during the study of variation of English and Azerbaijani words denoting the function of adverbial modifier of purpose.

I. The study of the theme shows that the places of the words denoting adverbial modifier of purpose are not stable in the compared languages.

II. The investigation of the materials has made it possible for us to note that in both compared languages sentences, composing of the same structure have different acoustic parameters.

III. In the Azerbaijani Language being a constituent part of Turkic Languages, word order is more flexible than that of English which refers to the analytical type of languages. Namely, In the Azerbaijani language words denoting adverbial modifier of purpose may be used in different parts of the simple sentences as to the word order, whereas this principle is more restricted for the English language. In both languages in the structure of the sentence depending on the variation of the position of the adverbial modifier of purpose, its informatics load changes too.

IV. In the pronunciation of invariants of simple sentences with adverbial modifier of purpose the intended in the norm structure + individual distinction aggregate. If in a simple sentence, the adverbial modifier of purpose is expressed not by a construction but only by an infinitive, in the pronunciation of the speaker the variation features change, namely, in order to denote the adverbial modifier of purpose only one lexeme is used.

$\mathrm{V}$. The variation features in the speech act can be considered as the bearer of the information, so, we can say, that the position of adverbial modifier of purpose within the simple sentences changes the character of variation of the speech act.

\section{References}

Abdullayev, K. M. (1998). Theoretical problems of the syntax of the Azerbaijani language. Baku, Maarif,

Bolinger, D. Z. (1958). A Theory of Pitch Accent in English. Word, 14(2/3).

Bolinger, D. Z. (1965). Forms of English. Cambridge, Mass.

Bresnan, J. (1971). Sentence stress and syntactic transformations. Language, 47.

Budagova, Z. (2003). Simple sentences in the modern linguistics. Baku, Education.

Chalek, S. C. (1992). Current English Grammar. Macmillan.

Crystal, D. (1969). Prosodic Systems and Intonation in English. Cambridge: Cambridge University Press.

Fakhraddin, Y. (2003). Introduction to German Linguistics. Baku, Education.

Gimson, A. C. (1956). The Linguistic relevance of stress in English. Zeitschrift für Phonetik, 2.

Gleason, H. A. (1965). Linguistics and English Grammar. London.

Goldsmith, I. A. (1987). Tone and accent and getting the two together. Berkeley Linguistic Society: Proceedings 13.

Gorshkov, A. I. (1981). Issue on norm variance Literary norms and variance. Moscow, Nauka.

Lyons, J. (2002). Linguistic Semantics. An Introduction. Cambridge.

Modern Azerbaijani language. (1959). ASU.

Potter, S. (1975). Language in the Modern world. London.

Sommerstein, A. H. (1977). Modern phonology. London.

Taghizadeh, Z. K. (1960). Syntax of the Modern Azerbaijani language. API. 
Yunusov, D. N. (2005). A Guide to English Grammar. Baku.

Yunusov, D. N. (2008). Constancy and variation in compound syntactic units. Baku: "E.L." Publishing LLC.

\section{Copyrights}

Copyright for this article is retained by the author(s), with first publication rights granted to the journal.

This is an open-access article distributed under the terms and conditions of the Creative Commons Attribution license (http://creativecommons.org/licenses/by/3.0/). 